\title{
ALBERTA'S ENERGY AND UTILITIES BOARD AND THE CONSTITUTION OF CANADA
}

\author{
NiCKIE VI.AVIANOS*
}

The author explores the jurisdictional ability of an adminisirative iribunal - specifically, the Alberia Energy and Unilities Board (EUB) - Io decide constitutional matters. She focuses particularly on tribunal decisions relating to Chartet rights and Aboriginal or treaty rights (s. 35(1)) and examines the recent decisions of Martin and Paul from the Supreme Court of Canada. The author concludes that for questions of law, the EUB has not only the option but the duty to consider constitutional questions.
Lauteur explore la capacide juridictionnelle d'un Iribunal administratif. tout particulièrement le Alberta tinergy and Vilinies Board (EUB). à trancher des questions constimuionnelles. Ellle cible surtout les décisions du tribunal portam sur les droirs de la Charte. les droits des peuples autochtones ainst que les droits issus d'un iraini (l. 35(I)) et étudie les récentes décisions de Martin el Paul de la Cour suprème du Canada. L'auteur conchut qu'en ce qui concerne les questions de droil, le EUB n'a pas sentement loption mais anssi le devoir de tenir comple des quesions constimtionnclles.

\section{TABLE OF CONTENTS}

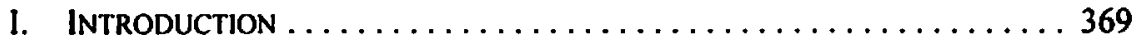

II. RAISING CONSTITUTIONAL RIGHTS ISSUES

BEFORE THE EUB ............................. 371

A. Challenge to Constitutional Validity of a Provision

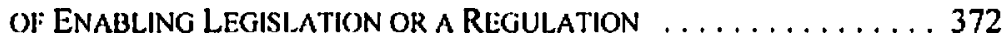

B. CONSTTUTIONAI. RIGHTS ISSUI: ARISING WIIEN

INTIRPRETING A QUESTION OF LAW ............... 377

C. CONSTTtUTIONAL RightS ISSUf: ARISING THROUGH

EXERCISE OF DISCRETION .................... 379

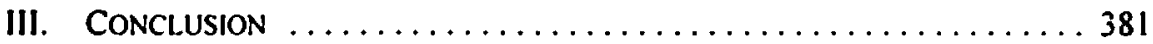

\section{INTRODUCTION}

Administrative boards and tribunals make decisions that itm,act our lives on a daily basis. In Alberta, the Energy and Utilities Board (the EUB or Board) makes decisions that affect the lives of Albertans in fundamental ways. In deciding which oil and gas activities to allow, the EUB must consider the economic, social and environmental effects of a particular project.' Along with the many economic benefits, oil and gas activities have the potential to impact negatively upon property values, the use of land, human health, livestock health and culture or ways of life. ${ }^{2}$

Research Associate with the Canadian lisslitute of Resuurces Law at the University of Calgary. This article was restarched as pan of a joint project between the lnstitule and the Alberta Civil Liberties Research Centre entitled "I luman Rights and Resource Development." The project has been generously funded by the Alberta Law Foundation.

Energy Resources Conservation .ICt, R.S.A. 2000, c. E-10. S. 3 |ERCA].

See for example. Thomas Marr-l.aing \& Chris Severson-Baker. Beyond Eco-Terrorism: The Deeper Issues Affecting Alberia's Oilpatch (Drayton Valle). Alta.: Pembina Institute for Appropriate Development, 1999). 
This article considers the mandate of the EUB with respect to rights protected by the Constitution of Canada. Increasingly, those affected by oil and gas development are looking for new ways to protect what they believe are fundamental human rights - constitutional rights. In the case of impacts to health, it has been argued that the right to life, liberty and security of the person in 5.7 of the Charler of Rights and Freedoms ${ }^{3}$ might be triggered by health effects from environmental impacts. ${ }^{4}$ In the case of impacts of development on culture or ways of life, Aboriginal peoples have long argued that EUB decisions should consider $s$. 35 (1) of the Constitution $A c t, 1982^{5}$ which recognizes and affirms Aboriginal and treaty rights in Canada.

Until recently, the law on whether administrative tribunals have the jurisdiction to determine constitutional questions, including Charter and Aboriginal rights questions, was not entirely clear. A number of Supreme Court of Canada decisions had caused nothing short of confusion.?

Perhaps owing to this state of the law, it appears that the EUB has not always considered constitutional questions to be part of its mandate. In a case where $\mathrm{s}$. 7 of the Charter was raised before the Board in regard to possible health effects of a project, the Board significantly reduced the intervener's costs award on the ground that the question was "not related to the issues in conflict at the proceeding." of Aboriginal or treaty rights under s. 35(1) of the Constitution, the EUB has taken the view that it "does not believe treaty rights or land claims are within its jurisdiction."

Canadian Charter of Rights and Freedoms. Part I of the Constitution Act. 1982, being Schedule B to the Canada ACr 1982 (U.K.), 1982, c. 11 [Charter].

- See for example, Transcript of Proceedings before the EUB, Application by Bonterra Energy Corp. Application No. 1259219 (6\& 7 November 2002). See also: Wierv. British Columbia (Environmental Appeal Board) (2003), 19 B.C.L.R. (4th) I78, 2003 BCSC 144I, where it was argued that a forestry permit authorizing the use of pesticides might violate $s$. 7 of the Charrer because of impacts to human health.

Constitution Act, 1982 being Schedule B to the Canada Act 1982 (U.K.). 1982, c. 11 [Constitution]. It should be noted that this articie does not address constitutional division of powers issues that might arise before energy tribunals. On these, see for example: Fulton v. Alberla (Energy Resources Conservation Board), [1981] I S.C.R. 153; and Wesicroast Energy Inc. v. Canada (National Energy Board). [1998] I S.C.R. 322.

See Douglas/Kwantlen Faculty Association v. Douglas College, [1990] 3 S.C.R. 570; Cuddy. Chicks v. Ontario (Labour Relations Bourd). [1991] 2 S.C.R. 5: Térreault-Gadoury v. Canada (Employment and Immigration Commission), (1991] 2 S.C.R. 22; Cooper v. Canada (Human Rights Commission), [1996] 3 S.C.R. 854 [Cooper]. For a good analysis of these cases, see Peter W. Hogg. Constitutional Law of Canada, 2004 student ed. (Toronto: Carswell, 2004) at 880-85. Energy Cost Order ECO 2003-105. In the Maller of Bonterra Energy Corp. Application for a Well Licence Pembina Area, Application No. 1259219 (2003) (AEUB) at 3.

" ERCB. Comvest Exploration Co. Lid. Decision D 94-6 (12 August 1994) at 15. See also: tERCB. Application for an Exploratory Well. Amoco Canada Petroleum Co. Lid. Whaleback Ridge Area. Decision D 94-8 (6 September 1994) at 7-8. Three recent cases where constitutional rights were raised by First Nations in the context of oil and gas approvals by the EUB were granted leave by the Alberta Court of Appeal: Dene Tha 'First Nation v. Alberta (Energy' and UVilitie. Board). [2003] A.J. No. 1582 (QL). 2003 ABCA 372 [Dene Tha 'First Nation]; Frog Lake First Nation v. Alberta (Energy and Utilities Board), [2003] A.J. No. 1583 (QL), 2003 ABCA 373; and Whitefish Lake First Nation v. Alberia (Energy and Utilities Board) (2004), 12 Admin. L.R. (4th) 114, 2004 ABCA 49 [Whitefish] 
This article considers whether the EUB's position on its jurisdiction with respect to the Constitution of Canada is correct, especially in light of two recent decisions by the Supreme Court of Canada. The article sets out three scenarios for how constitutional rights issues might arise before the EUB (or before any other administrative tribunal for that matter) and then examines the law with respect to each. It concludes that, however the issue may arise, the EUB has the jurisdiction to, and in fact must, decide the constitutional question brought before it. ${ }^{10}$

\section{Raising CONStitutional. Rights Issues Before the EUB}

There are conceivably three different ways in which issues of constitutional rights could arise before the EUB. First, a challenge to the constitutional validity of a legislative or regulatory provision within the EUB's jurisdiction could be made. Although this would likely be rare, it is not inconceivable. For example, if 5.7 of the Charter does provide some health protection from environmental impacts, it may be that s. 28(1) of Alberta's ERCA (which grants intervener costs only to those who have an actual interest in the land affected by an EUB decision) may violate this Charter right. Or, perhaps a regulation under an energy statute that allows for a certain amount of pollution may be in violation of health aspects protected by s. 7 of the Charter."

Second, a constitutional rights issue could arise before the EUB when the Board is required to determine a legal issue or an issue of mixed fact or law in making its decision. The clearest example of such a situation would be in regard to the test for standing for a hearing in s. 26(2) of the ERCA where the term "rights" is actually used in the legislation. Section 26 (2) grants a hearing to anyone whose rights may be directly and adversely affected by a Board decision. In interpreting what is encompassed by the term "rights" in this provision, it is arguable that the EUB must consider both the rights protected by the Charter and the Aboriginal and treaty rights referred to in s. 35(1) of the Constitution. In short, the argument would be that, in determining a question of law, the EUB must look to the Constitution as part of that law.

A third scenario in which a constitutional issue could arise before the EUB is through an argument that the exercise of the Board's discretion in a particular way (for example, by approving a project as being in the public interest) will violate certain constitutional rights. For instance, it might be argued that, by allowing certain types or levels of pollution in approving a project, the EUB's decision will have the effect of violating certain health rights

10. Subsequent to the writing of this article, the Alberta Legislature assented to an Act that seeks to remove the jurisdiction to determine questions of constitutional rights from administrative tribunals in Alberta: Administrative Procedures Amemiment ACI. 2005, S. A. 2005. c. 4 (assented to 10 May 2005). The Act requires regulations to be passed that specifically grant such jurisdiction to particular decision makers. As of 20 June 2005 . the $A c t$ had yet to be proclaimed in force. but when it is, it could have important consequences for the application of tlec common law reviewed in this article to the FUB. The Act's proclamation will also undoubtedly raise questions about the validity of this type of tegislation. Vlavianos, Healih, Human Righss and Resource Development in Alberia: Current and Emerging Law (Calgary: Canadian Institute of Resources L.aw, 2003). 
protected under s. 7 of the Charter; or that the approval of wells or pipelines will infringe Aboriginal or treaty rights to hunt, trap or fish protected by s. 35(1) of the Constitution.'

The law in regard to each of these three scenarios will be discussed below. As will be seen, it is almost certain that the EUB has the jurisdiction to, and must, determine constitutional rights issues if they arise through either the first or second scenario outlined above. As for the third way in which constitutional questions might arise before the Board, the law is clear that EUB decisions and orders (and the exercise of discretion generally) must not violate the principles of the Constitution of Canada.

\section{A. Challenge to Constitutional Validity of a Provision of Enabling Legislation or a Regulation}

\section{THE MARTIN DECISION}

After a series of confusing cases, the Supreme Court of Canada has recently clarified the law regarding the jurisdiction of administrative tribunals to consider the constitutional validity of a provision of their enabling statute. In a decision rendered in October 2003, the Court unanimously held that those administrative tribunals that have been granted the power to decide questions of law have the power to decide whether a provision in their enabling (or subordinate) legislation violates the Constitution or, in that case, the Charter. It follows that tribunals with such a power have a corresponding duty to decide constitutional questions where necessary to determine matters before them.

In Nova Scotia (Workers' Compensation Board) v. Martin, ${ }^{13}$ a provision of the workers' compensation legislation of Nova Scotia, as well as a regulation adopted under that $A c t$, excluded chronic pain from coverage. Two employees who were denied benefits by the Nova Scotia Workers' Compensation Board appealed the decision to the Nova Scotia Workers' Compensation Appeals Tribunal (an administrative tribunal set up to hear appeals from decisions of the Board). They argued that the relevant legislative provision and regulation violated their equality rights under $s .15$ of the Charter. The Appeals Tribunal agreed and declined to apply the challenged provisions to the appellants.

Before the Supreme Court of Canada, the issue was whether the Appeals Tribunal had jurisdiction to decide the constitutionality of the challenged provisions. According to the Court, the rule concerning the jurisdiction of administrative tribunals to apply the Charter is as follows:

Administrative tribunals which have jurisdiction - whether explicit or implied - to decide questions of law arising under a legislative provision are presumed to have concomitant jurisdiction to decide the constitutional validity of that provision. This presumption may only be rebutted by showing that the legislature clearly intended to exclude Charter issues from the tribunal's authority over questions of law. ${ }^{14}$ for example, see Monique M. Passelac-Ross. The Trapping Rights of Aboriginal Peoples in Northern Alberia, Occasional Paper \#15 (Calgary: Canadian Institute of Resources Law, 2005). 
For the Court, Gonthier J. cited a number of reasons for allowing administrative tribunals to decide the constitutional validity of a provision of their enabling statute, and for allowing them to refuse to apply the challenged provision if found to violate the Constitution. First, and most importantly, the Court cited s. 52(1) of the Constitution which states that the Constitution is the supreme law of Canada, and any law that is inconsistent with its provisions is, to the extent of the inconsistency, of no force or effect. In the Court's view, the invalidity of a legislative provision inconsistent with the Charter does not arise from it being declared unconstitutional by a court. Rather, given s. 52(1), such a provision is invalid from the moment it is enacted (and a judicial declaration to this effect is simply one remedy amongst others to protect those whom the provision adversely affects). In this way, "by virtue of s. $52(1)$, the question of constitutional validity inheres in every legislative enactment."15

Moreover, just as courts may not apply invalid laws, the same holds true for every level and branch of government, including administrative organs of the statc. As stated by Gonthier J.:

\begin{abstract}
Obviously, it cannot be the case that every government official has to consider and decide for herself the constitutional validity of every provision she is called upon to apply. If, however. she is endowed with the power to consider questions of law relating to a provision, that power will normally extend to assessing the constitutional validity of that provision. This is because the consistency of a provision with the Constitution is a question of law arising under that provision. It is, indeed, the most fundamental question of law one could conceive, as it will determine whether the enactment is in fact valid law, and thus whether it ought to be interpreted and applied as such or disregarded. ${ }^{16}$
\end{abstract}

Another reason given by the Court for allowing administrative tribunals to determine questions of constitutional validity is the idea that Canadians should be entitled to assert the rights and freedoms which the Constitution guarantees in the most accessible forum available, without the need for parallel proceedings before the courts. Since many administrative tribunals have exclusive initial jurisdiction over disputes relating to their enabling legislation, requiring litigants to refer constitutional issues to the courts would result in costly and timeconsuming bifurcation of proceedings. In addition, according to the Court, the factual findings and record compiled by an administrative tribunal, as well as its views of the various issues raised by a constitutional challenge, will often be invaluable to a reviewing court. ${ }^{17}$

Finally, the court emphasized that administrative tribunal decisions based on the Charter are subject to judicial review on a correctness standard. An error of law by an administrative tribunal interpreting the Constitution is fully reviewable by a superior court.

Thus, in Martin, the Supreme Court concluded that the first question to be addressed in each case is whether the particular administrative tribunal has the jurisdiction, explicit or

lbid. at para 28.

lbid.

It should be noted, though, that the constitutional remedies available to administrative tribunals are limited. They do not include general declarations of invalidity. Rather, a tribunal that determines that a provision of its enabling statute is unconstitutional is limited to refusing to apply the provision in the particular case before it, and such a determination is not binding on future decision makers: ibid. at para. 3 I. 
implied, to decide questions of law arising under the challenged provision. If it does, then it will be presumed to have the concomitant jurisdiction to interpret or decide that question in light of the Constitution, including the Charter, unless the legislator has removed that power from the tribunal.

Here, the Nova Scotia legislature had expressly conferred the authority to decide questions of law on the Appeals Tribunal in its enabling legislation. In particular, a statutory section provided that the Appeals Tribunal could determine "all questions of fact and law" arising pursuant to the legislation, and there was no indication in the legislation that the legislature had intended to exclude the Charter from the scope of the Appeal Tribunal's authority. Thus, Gonthier J. held that the Appeals Tribunal had the "explicit jurisdiction to decide questions of law arising under the challenged provisions, a jurisdiction which is presumed to include the authority to consider their constitutional validity."18

The Court was clear, however, that such a broad grant of jurisdiction is not necessary to confer on an administrative tribunal the power to apply the Charter. In its view, implied jurisdiction to decide questions of law arising under the challenged provision can be discerned in each case by looking at the relevant statutory scheme as a whole. Justice Gonthier stated as follows:

\begin{abstract}
Relevant factors will include the statutory mandate of the tribunal in issue and whether deciding questions of law is necessary to fulfilling this mandate effectively: the interaction of the tribunal in question with other elements of the administrative system; whether the tribunal is adjudicative in nature: and practical considerations, including the tribunal's capacity to consider questions of law. Practical considerations. however, cannol override a clear implication from the statule itself, particularly when depriving the tribunal of the power to decide questions of law would impair its capacity to fultill its intended mandale. As is the case for explicit jurisdiction. if the tribunal is found to have implied jurisdiction to decide questions of law arising under a legislative provision, this power will be presumed to include jurisdiction to determine the constitutional validity of that provision. ${ }^{19}$
\end{abstract}

As for whether this presumption has been rebutted. Gonthier J. stated that an explicit withdrawal of authority to decide constitutional questions or by a clear implication to the same effect would be necessary. This withdrawal would have to come from the statute itself rather than from external considerations.

Justice Gonthier also clarified that practical considerations will not easily oust a tribunal's mandate to decide constitutional questions. In response to the Workers' Compensation Board's argument that it did not possess the resources or expertise to deal with numerous Charter cases, Gonthier J. stated as follows:

Of course, as a malter of statulory interpretation, the Board's own view is not determinative of its jurisdiction.

As La Forest J. noted in Cuddy Chicks, referring to the Ontario Labour Relations Board (at p. 18):

At the end of the day, the legal process will be better served where the Board makes an initial determination of the jurisdictional issue arising from a constitutional challenge. In such 
circumstances, the Board not only has the authority but a duty to ascertain the constitutional validity of 3. 2(b) of the Labour Relations Act.

Likewise, in the present appeal, the Act clearly contemplates that the Board will decide questions of law. Practical considerations cannot override the clear expression of legislative intent in [the enabling legislation]. ${ }^{20}$

In short, administrative tribunals that have been given the power to determine questions of law not only have the jurisdiction to determine questions about the constitutional validity of their enabling statutes, but they must do so when they arise.

\section{APPLICATION TO THE EUB}

As noted, in Martin, the Supreme Court of Canada clarified the rules for when an administrative tribunal has the authority to subject provisions in its enabling legislation to Charter scrutiny. It has this authority when that tribunal has been given the power to determine questions of law by its enabling legislation.

Although there is no express grant of this power in the EUB's enabling legislation, there are provisions throughout the three main statutes that empower the EUB in the oil and gas context that indicate that the Alberta legislature intended the EUB to decide questions of law. These provisions impliedly grant the EUB the power to decide general questions of law, as well as questions about the construction of its own legislation. ${ }^{21}$

First, s. 94 of the $O G C A$ states that, except where otherwise provided, "the Board has exclusive jurisdiction to examine, inquire into, hear and determine all matters and questions arising under this Act. ${ }^{22}$ In $R$. v. Kállodééche First Nation, ${ }^{23}$ Vertes J. held that a provision of the Canada Labour Code ${ }^{24}$ providing the Canada Industrial Relations Board with the power to "decide for all purposes of this Part any question that may arise in the proceeding" included the power to determine questions of law. According to Vertes J.: "The power to decide any question must necessarily include questions of law." ${ }^{25}$ Applying this reasoning to s. 94 of the $O G C A$ suggests that the EUB has been empowered to determine all general questions of law arising under its legislation.

When one also looks at the purposes of the OGCA, it is difficult to envision how the EUB could carry out its mandate without determining questions of law. In particular, s. 4(d) states that one of the purposes of the $A C t$ is to "afford each owner the opportunity of obtaining the owner's share of the production of oil or gas from any pool." Clearly, this requires a determination of who an owner is, which is a question of mixed fact and law.

Ibid. at para. 63 [emphasis added by Gonthier J.]. Nonetheless, in Paul v. British Columbia (Forest Appeal Commission), [2003] 2 S.C.R. 585. 2003 SCC 55 [Pail], the Supreme Court did acknowledge that practical considerations may be relevant in determining the most appropriate way of handling a particular dispute where more than one option is available (at para. 39). The statutes reviewed are: the Alberla Energy and Utilities Board Acr, R.S.A. 2000, c. A-17| AEIIIS $A c t]$; the Oil and Gas Conservalion ACI. R.S.A. 2000, c. O-6 [OGCA]: and the ERC $A$. supra nute I OCCA. ibid. [emphasis added]. [2004] 8 W.W.R. 233. 2003 NWTSC 70.

Canada Labour Cade. R.S.C. 1985. c. L-2. The provisions in question are s. $16(0.1)$ and (p). Supra note 23 at para. 53 [emphasis in original]. 
Similarly, other provisions of the EUB's enabling legislation indicate that the Board will have to determine legal questions. All of the following contain legal aspects:

- s. 16(1) of the OGCA states that no one shall apply to the Board for a licence unless that person is a working interest participant and is entitled to the right to produce the oil, gas or crude bitumen from the well. "Working interest participant" is defined in s. 1(1)(fff) as a "person who owns a beneficial or legal undivided interest in a well or facility under agreements that pertain to the ownership of that well or facility."

s. 26(2) of the ERCA directs the Board to hold a hearing if "it appears to the Board that its decision on an application may directly and adversely affect the rights of a person." The Alberta Court of Appeal has repeatedly held that the test for standing in this provision is a legal one. ${ }^{26}$

s. 28(1) of the $E R C A$ defines who a local intervener is for purposes of costs as "a person or a group or association of persons who, in the opinion of the Board, (a) has an interest in, or (b) is in actual occupation of or is entitled to occupy land that is or may be directly and adversely affected by a decision of the Board."

Clearly, each of these provisions contains legal questions that the EUB will have to deal with as they arise.

Perhaps the most compelling evidence that the EUB is empowered to determine questions of law is found in s. 26(1) of the $A E U B A C l$ which provides for an appeal from the Board to the Alberta Court of Appeal on a "question of jurisdiction or on a question of law." In Paul, discussed further below, a unanimous Supreme Court of Canada concluded that such an appeal provision clearly implies that a tribunal has been empowered to determine legal questions (and not simply purely factual matters). ${ }^{27}$

A final note should be made about the fact that the EUB is undoubtedly an adjudicative tribunal. It refers to itself as a "quasi-judicial" tribunal. ${ }^{28}$ Although in Martin the Supreme Court held that the adjudicative nature of an administrative body is not a necessary factor in the search for implicit jurisdiction to determine questions of law, the Court was clear that it is an important factor in finding such an implied power. ${ }^{29}$

3. See most recently, Dene Tha ' First Nation, supra note 9: Whitefish, supra note 9: and Dene Tha 'First Nation v. Alberia (Energy and Utilities Board) (2005), 363 A.R. 234. 2005 ABCA 68 at para. 10.

27 Supra note 20 (Paul concerned the Forest Practices Code of British Columbia Act. R.S.B.C. 1996. C 159 at ss. $131(8)$ \& $14 \mid(1))$. Of course there are many examples of appeals brought to the Alberta Court of Appeal on a question of law from an EUB decision. Two recent examples ase: Alberta Energy Co v. Goodwell Petroleum Corp. (2003), 339 A.R. 201, 20113 ABCA 277: and Beau Canuda Exploration Lid. v. Alberia Energy and Unilines Board (2000), 26I A.R. 131, $2000 \mathrm{ABCA} 132$.

:" See for example, the EUB's Working for Albertans: 2002 Year-End Review' (Calgary: Alberta Energy and Utilities Board. 2003) at 6, where it describes itself as a "provincial, quasi-judicial agency of the Alberta government that regulates Alberta's energy resources and utilitics."

$\because \quad$ Martin, stupra note 13 at para. 54. In rejecting the notion that the adjudicative nature of a tribunal is determinative, the Supreme Court in Martin overruled aspects of a prior decision of the Court (at para. 47). Cooper. supra notc 7 
The EUB undoubtedly exercises adjudicative functions when it issues licences and authorizations for various oil and gas activities in Alberta. It also has extensive powers of inquiry and investigation and its enabling statutes reveal an applicable adjudicative process. For instance, the EUB establishes its own rules of procedure pursuant to s. 27 of the ERCA. The Board (and any member of it) has all the powers of a commissioner appointed under the Public Inquiries $A c t,{ }^{30}$ including the power to summon witnesses, compel testimony and require production of documents. ${ }^{31}$ In Martin, the Court cited all of these factors as indicative of the adjudicative nature of the tribunal at issue in that case.

In sum, the EUB clearly has the power to determine general questions of law as well as questions about the interpretation of its enabling legislation. In fact, it must do so in order to fulfill its mandate as Alberta's energy regulator. Thus, based on Martin, if a question about the constitutional validity of a provision of its enabling legislation or of a regulation under that legislation were brought before the EUB, it would be extremely difficult for the Board to maintain that it does not have the authority or jurisdiction to determine this question.

\section{B. Constitutional Rigits Issue ARising WIJeN INTERPRETING A QUESTION OF LAW}

In Martin, the Supreme Court of Canada restricted its analysis of the jurisdiction of administrative tribunals to decide constitutional questions to the situation where a constitutional challenge is made to the tribunal's enabling legislation or to a regulation made under that legislation. But what about the situation where a constitutional challenge to a specific provision is not made, but rather a constitutional issue arises in the course of interpreting a question of law under an applicable statute?

Released concurrently with Martin, the case of Pau/ ${ }^{32}$ goes further than Marrin and appears to address this question. In Paul, the Supreme Court framed the issue more broadly than the scenario of a constitutional challenge to enabling legislation. Rather, according to the Court in Paul, the issue in that case concerned generally "the power of administrative tribunals to determine questions of constitutional law." 33 More specifically, the case concerned whether a province could constitutionally confer on administrative tribunals the power to determine questions of Aboriginal rights under s. 35(1) of the Constitution as those questions arise in the course of the tribunal's duties.

The facts in Paul involved Thomas Paul, a registered Indian, who had cut trees to build a deck on his home. Mr. Paul asserted that he had an Aboriginal right to cut timber for house modification and, accordingly, that the provincial legislation establishing a general prohibition against cutting Crown timber did not apply to him. On appeal to the British Columbia Forest Appeals Commission (the Commission), an issue arose as to whether the Commission had the jurisdiction to hear Mr. Paul's defence that he had exercised his

\footnotetext{
R.S.A. 2000, c. P.39.

lbid., ss. 4-5.

Supra note 20.

lbid. at para. 39.
} 
Aboriginal rights under s. 35(1) of the Constitution. The Commission concluded that it did, but a subsequent appeal to the British Columbia Court of Appeal reversed this decision.

The Supreme Court of Canada held that, where an administrative tribunal has been empowered to determine questions of law, there is a presumption that it may decide questions of Aboriginal law, including constitutional law. In applying their enabling legislation, administrative boards must take into account all applicable legal rules.

The question of whether the provincial legislature has so empowered a particular tribunal is, according to the Court, answered by applying the approach in Martin. The approach set out in the context of determining a tribunal's power to apply the Charter is also the approach to be taken in determining a tribunal's power to apply s. 35(1) of the Constitution. According to Bastarache $\mathrm{J}$. for the Court, the essential question is whether the enabling legislation implicitly or explicitly grants the tribunal the jurisdiction to interpret or decide any question of law. If it does, the tribunal will be presumed to have the concomitant jurisdiction to interpret or decide that question in light of s. 35(1) or any other relevant constitutional provision.

Noting that there is no requirement for an express empowerment that administrative tribunals be able to apply the Constitution in their enabling legislation, Bastarache J. concluded that the statutory mandate given to the Commission in this case required it to determine questions of law. Consequently, in his view, the Commission had been granted the power to decide questions relating to Aboriginal rights arising incidentally to forestry matters, and there was no evidence of either an express or implied withdrawal of this power by the legislature.

In sum, the case of Paul makes clear that, where a constitutional question arises in the course of an administrative tribunal exercising its mandate, the tribunal has the jurisdiction to determine that question if it has been empowered to determine questions of law. Not only does it have the jurisdiction to do so, however, as noted by Wittman J.A. in Whitefish,$^{34}$ the Paul decision also stands for the proposition that "regulatory boards, empowered to consider matters of law, must take claims of [A]boriginal and treaty rights into account when exercising their statutory mandate."'"

Thus, since the EUB has been granted the power to determine questions of law as outlined above, it must look outside its enabling legislation to all relevant law that is necessary in order to determine the legal questions before it. This law includes the Charser and s. 35(1) of the Constitution. Of course, any decision by the EUB regarding the Constitution is reviewable on a standard of correctness. ${ }^{36}$

The Alberta Court of Appeal has very recently recognized the importance of the Constitution in the general body of law that the EUB must consider in its decision-making.

Supra note 9.

lbid. at para. 19 [emphasis added].

See Martin, supra note 13 at para. 31 and Paul, supra note 20 at para. 31. 
In Dene Tha' First Nation, ${ }^{37}$ the appeal centred on the test for standing in s. $26(2)$ of the $E R C A$ which, as noted earlier, grants standing for a hearing before the Board to anyone whose "rights" may be directly and adversely affected by a Board decision. According to the Court, the first part of the test, the legal part, requires the Board to ask whether the claimed right or interest is one known to the law, and this includes constitutional law. In the Court's view, "[o]bviously a constitutional, a legal or an equitable interest would suffice" this test. In short, the EUB must consider questions of constitutional rights where this is necessary to properly address the matters before it.

\section{CONSTITUTIONAL RIgHTS ISSUE ARISING THROUGH EXERCISE OF DISCRETION}

As noted above, constitutional rights issues could arise before the EUB either through a direct constitutional challenge to the validity of legislation, or because the EUB has to consider constitutional law in order to decide a particular question of law within its mandate. Questions of constitutional rights could, however, also arise before the Board in another way. In this scenario, an argument could be made to the Board that the exercise of its discretion in a particular way (for example, by approving a project as being in the public interest) would violate certain constitutional rights.

As regards the rights and freedoms guaranteed by the Charter, the law is clear that all persons exercising statutory authority must comply with its provisions, even if they are independent of government. ${ }^{39}$ Consequently, orders and decisions made by administrative bodies (such as the EUB) must not violate the rights and freedoms protected by the Charter.

In Slaight Communications Inc. v. Davidson, an adjudicator appointed by the Minister of Labour under the Canada Labour Code concluded that an employee had been unjustly dismissed. Based on powers granted under the Code, the adjudicator made an initial order obliging the employer to provide the employee with a letter of recommendation setting out certain particulars. A second order prohibited the employer from answering any request for information about the employee except by sending this letter of recommendation. Before the Supreme Court of Canada, the employer argued that both orders violated the company's freedom of expression under s. 2(b) of the Charter.

The Supreme Court was unanimous that the Charter applied to the orders made by the adjudicator in this case. Since the adjudicator was created under statute, and derived all his powers from statute, the Court concluded that he did not have the power to make any order that would result in an infringement of the Charfer. According to Lamer J., since:

[T] he Constitution is the supreme law of Canada and any law that is inconsistent with its provisions is. to the extent of the inconsistency, of no fore or effect, it is impossible to interpret legislation conferring discretion as conferring a power to infringe the Charter, unless, of course. that power is expressly conferred or 
necessarily implied. Such an interpretation would require [the Court] to declare the legislation to be of no force or effect, unless it could be justified under s. 1 [of the Charter]. ${ }^{40}$

Thus, according to Lamer J., an adjudicator exercising delegated powers does not have the power to make an order that would result in an infringement of the Charter.

Subsequently, in Baker v. Canada (Minister of Citizenship and Immigration), the Supreme Court of Canada reiterated its view that discretion must be exercised in accordance with the principles of the Charter. This is so even where the discretion granted is very broad.

Clearly, Alberta's EUB is captured by this case law. Whenever the EUB exercises its discretion under statute, it must have due regard for the rights and freedoms protected by the Charter. If a decision or order fails to do so, a court could strike it down as invalid, or remit the case back to the Board for a more proper exercise of its discretion. As summarized by one commentator:

\begin{abstract}
The rights and freedoms enshrined in the (harter may constitute factors that have to be taken into account in the exercise of a discretion, and a finding of failure to take them into account could produce not simply a quashing of a decision but also a remission back to the decision maker to perform the task once again, this time in the context of the Charter and a correct appreciation of its meaning and demands. ${ }^{42}$
\end{abstract}

The same holds true in regard to Aboriginal and treaty rights protected by s. 35(1) of the Constitution. In a number of cases, it has been argued that the exercise of an administrative board's discretion in approving a particular development has effectively infringed upon s. 35 ( 1 ) constitutional rights. ${ }^{43}$ In response, the courts have held that administrative boards must ensure that their decisions do not operate in this way.

In the case of Hydro-Quebec, the Supreme Court of Canada considered whether the National Energy Board's decision to grant licences to Hydro-Quebec for the export of electrical power would have the effect of negatively impacting on Aboriginal rights protected by s. 35(1) of the Constitution. In rendering its decision, a unanimous Court held as follows in regard to whether administrative boards must exercise their discretion in accordance with the Constitution of Canada:

It is obvious that the [National Energy] Board must exercise its decision-making function, including the interpretation and application of its governing legislation, in accordance with the dictales of the Constitution. including s. 35(1) of the Constitution Act. 1982. Therefore, it must first be determined whether this particular decision of the Board, made pursuant to s. $119.08(1)$ of the National Energy Board Act, could have the effect of interfering with the existing (A)boriginal rights of the appellants so as to amount to a prima facie infringement of $s .35(1)^{44}$

w.

David J. Mullan. Administrative Lanr (Toronto: Irwin L.aw, 2001) at 124.

"See for example, Que hec (Allorney General) v. Canada (National Energy Board). [1994] I S.C.R. 159 [Hydro-Quebec] and, more recently, Sautheau First Nations v. British Columbia (Oil and Gas Commission), [2004] 4 C.N.L.R. 284, 2004 BCSC 92, afl'd [2004] 4 C.N.L.R. 340, 2004 BCCA 286. Hydro-Quebec, ibid. at 185. 
Although not explicitly stated, the rationale behind this view is likely that expressed in Slaight in the context of the Charter. As stated in s. 52(1) of the Constitution, the Constitution of Canada is the supreme law and any law that is inconsistent with its provisions is of no force or effect. Thus, federal and provincial legislation that empowers administrative tribunals must be read so as to not authorize infringements of constitutional rights. In short, federal and provincial administrative boards, including Alberta's EUB, have a responsibility to render decisions that do not offend the Constitution.

\section{CONCLusion}

Whatever the law may have been previously, the Supreme Court of Canada has recently clarified that administrative bodies with the power to determine questions of law have the power to decide questions of constitutional law (unless that power has specifically been removed by the legislature). Further, not only do such administrative boards have this jurisdiction, they have a duty to determine constitutional questions when necessary to address matters properly before them.

A review of the EUB's enabling legislation suggests that the EUB has been empowered to determine questions of law in the context of approving energy projects in Alberta. Further, there is no indication that the Legislature intended to remove constitutional questions from EUB jurisdiction. Consequently, the Board must determine questions of rights under the Charter and under s. 35(1) of the Constitution whenever those questions relate to matters before the EUB. This is so whether a constitutional rights issue arises before the Board through a challenge to a legislative provision or regulation, or whether it arises as part of a question of law that the Board must determine to resolve the matters before it.

The EUB must also be mindful of the Constitution in another way as well. The Supreme Court of Canada has held that, whenever administrative bodies exercise their discretion or their decision-making powers under their enabling legislation, those bodies must be careful to comply with the dictates of the Charter and of s. 35(1) of the Constitution. In short, EUB decisions and orders must not violate the Charter or s. 35(1) of the Constitution.

Although the law on the constitutional jurisdiction of administrative tribunals appears settled now, jurisdiction is simply an important first step in the process. In the context of oil and gas development in Alberta, it is fairly easy to say that the EUB has the jurisdiction to determine constitutional rights issues. The really hard part is saying how the EUB should determine those issues in any given case before it. 